Sains Malaysiana 50(11)(2021): 3365-3372

http://doi.org/10.17576/jsm-2021-5011-20

\title{
Estimated Effective Lifetime Risks of Radiation-Induced Thyroid Cancer in Computed Tomography (CT) Brain Examination
}

(Anggaran Keberkesanan Risiko Sepanjang Hayat Kanser Tiroid Disebabkan Radiasi dalam Pemeriksaan Tomografi Berkomputer Otak)

\author{
ReKha Ganesan, Muhammad IkHmal Naim Mohd Hilal, Iza NurZaWani Che Isa*, Norhashimah

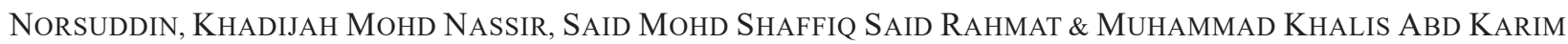

ABSTRACT

Thyroid is one of the most radiosensitive organs in the human body. Although the scanning range of brain computed tomography (CT) does not include lower neck region, there is possibility for thyroid to be irradiated due to scattered radiation because of its location near to the external beam collimation. The objective of this study was to evaluate effective lifetime risk of radiation-induced thyroid cancer in young adults following brain CT examination. A total of 306 patient data within the age range between 18 and 39 years old were retrospectively analysed. Absorbed dose of the thyroid organ was obtained through the input of data using WAZA-ARI v2. Effective lifetime risk was calculated by multiplying equivalent dose of the thyroid organ with the lifetime attributable cancer risk adapted from Biological Effects in Ionising Radiation (BEIR) Report V11. The effective lifetime risks were recorded as $0.45 \pm 0.70$ per 100000 and 0.93 \pm 1.52 per 100000 for single and multiple exposures, respectively. In terms of gender, woman data $(0.99 \pm 0.76 ; 1.95 \pm$ 2.15) were found higher as compared to man data $(0.13 \pm 0.39 ; 0.35 \pm 0.45)$ for both single and multiple exposure. The percentage difference of effective lifetime risks between single and multiple exposures was up to 107\%. The effective lifetime risk noted in this study may be low, however, the long-term risk of cancer development should be considered. This study serves as preliminary reference when revising clinical protocol especially in those involving repeated exposures in young adult patients. Future study should include other radiosensitive organs exploring the effective lifetime risk of radiation induced cancer following CT procedure.

Keywords: CT brain; effective lifetime risk; radiation risk; thyroid cancer; young adult

\section{ABSTRAK}

Tiroid ialah organ badan manusia yang sangat sensitif terhadap radiasi. Walaupun kawasan dedahan kepada radiasi semasa prosedur tomografi berkomputer (CT) otak tidak meliputi kawasan leher, namun begitu masih terdapat risiko radiasi yang diterima oleh tiroid kerana kedudukannya terletak berhampiran dengan kawasan kolimasi. Objektif kajian ini adalah untuk mengkaji risiko berkesan radiasi kanser tiroid sepanjang hayat dalam kalangan pesakit bagi peringkat awal dewasa yang menjalani pemeriksaan CT otak. Sebanyak 306 data pesakit antara umur 18 dan 39 tahun telah dianalisis secara retrospektif. Dos serapan tiroid dihitung menggunakan WAZA-ARI v2. Risiko berkesan sepanjang hayat dihitung menggunakan data tiroid dos setara dan data risiko pembentukan kanser yang diambil daripada Laporan V11, Biological Effects in Ionising Radiation (BEIR). Risiko berkesan sepanjang hayat telah dicatatkan sebagai $0.45 \pm 0.70$ bagi dedahan tunggal dan $0.93 \pm 1.52$ bagi dedahan berulang. Dari segi perbandingan antara jantina, data pesakit wanita $(0.99 \pm 0.76 ; 1.95 \pm 2.15)$ mencatatkan risiko berkesan yang lebih tinggi berbanding dengan data pesakit lelaki $(0.13 \pm 0.39 ; 0.35 \pm 0.45)$ bagi dedahan tunggal dan berulang. Peratusan perbezaan risiko yang dicatatkan adalah sehingga 107\%. Risiko berkesan sepanjang hayat yang dicatatkan dalam kajian ini mungkin rendah, namun begitu risiko jangka panjang perkembangan kanser perlu diambil kira. Kajian ini menunjukkan bahawa protokol untuk peperiksaan CT perlu disemak terutamanya kepada pesakit peringkat awal dewasa yang perlu menjalani prosedur CT secara berulang. Kajian pada masa hadapan perlu dilakukan merangkumi organ lain yang sensitif terhadap radiasi seperti bahagian peranakan dan mata.

Kata kunci: Awal dewasa; CT otak; kanser tiroid; risiko berkesan sepanjang hayat; risiko radiasi 


\section{INTRODUCTION}

Human, from the beginning of life, have been and still being exposed to radiation either from natural background or man-made sources radiation. By far, radiation for medical procedures including diagnostic X-rays has become the most significant source of man-made radiation. Computed tomography $(\mathrm{CT})$ is one of the most important diagnostic imaging tools uses ionizing radiation which may cause small increase in a human's lifetime risk of developing cancer. Stochastic risks is the main concern especially among paediatric patients due to several factor such as smaller body size, greater sensitivity to ionizing radiation and most importantly they have longer remaining life spans for the effects of radiation exposure to manifest as cancer (Abdulkadir et al. 2020). General practice of brain CT examinations, repeated CT scans are requested for mild traumatic brain injury cases (Trevisi et al. 2018). With the extensive use of CT examinations, patients that have undergone repeated exposures may experience a high cumulative dose that could raise concerns of late radiation-induced cancer (Ivanov et al. 2014; Sabarudin et al. 2019). When it comes to risk of radiation-induced cancer, most researches nowadays had focused on paediatric and geriatric patients. Despite a large number of cancers with worse overall survival rate being reported in the young adult age group (18 to 39 years-old) compared to older patients (Bleyer 2007). It is generally perceived by the community that risk of cancer in young adults is relatively lower than older age groups. Consequently, society and economy are heavily burdened by premature morbidity and mortality observed in this age group (Fidler et al. 2017).

It is known that thyroid can be deemed as a radiosensitive organ in human body, more so in children and young adults. Although the thyroid organ does not receive direct radiation from brain $\mathrm{CT}$ due to its scanning range, the incidence of thyroid irradiation due to scattered radiation is however still very much present (Mazonakis et al. 2007). The thyroid dose following a brain CT examination ranges from 1.10-2.8 mGy with little variation by age (Schonfeld et al. 2011; Su et al. 2014). The thyroid cancer has been reported as the strongest increase in incidence rate among Malaysians female from the year 2012 to 2016 (National Cancer Institute 2019). Nonetheless, the risk of radiation-induced thyroid cancer due to brain CT examination is unheard of by many. The fact that multiple CT scans done on a patient increases their risk in obtaining radiation-induced thyroid cancer is worrisome. The research concerning lifetime effective lifetime risk attributable to CT scanning is crucial and should be done continuously as part of reference to be used in optimizing scanning protocols especially at national level. Thus, this study was carried out to evaluate effective lifetime risk of radiation-induced thyroid cancer in young adults following single and multiple brain $\mathrm{CT}$ examinations.

\section{MATERIALS AND METHODS}

This research was conducted retrospectively through the collection of patient data from the Department of Radiology, Hospital Canselor Tuanku Muhriz UKM, Malaysia. Data collected were from young adult patients aged between 18 and 39-year-old between January and December 2018. All patients underwent brain scanning using multi-detector 640-slice CT scanner (Aquillion One TSX-301, Toshiba, Japan). Scanning parameters including tube potential, tube current, type of filter, rotation time, pitch factor and beam width were recorded. Research ethical approval was obtained prior to the data collection from the institutional ethics committee (UKM1.21.3/244/ NN-2019-048). The absorbed dose of the thyroid for each case was calculated using WAZA-ARIv2 (NIRS, Japan), a web-based calculator that was developed to estimate absorbed organ radiation dose of patients who underwent CT examination. Data such as manufacturer of the machine, type of filter used, tube potential, rotation time, pitch factor, beam width, gender, type of scan, begin position and end position, and tube current inserted into the software were obtained. The equivalent dose of the thyroid was then calculated for each patient using the following formula:

$$
H_{T}=\Sigma D_{R} W_{R}
$$

where $H_{T}$ is the equivalent dose; $D_{R}$ is the absorbed dose of the thyroid organ; and $W_{R}$ is the radiation weighting factor. The thyroid organ equivalent dose along with the lifetime tissue- specific cancer risk (2006) presented in BEIR VII report (Table 1), were used to calculate effective lifetime risk of thyroid cancer for the young adults age group. The age group were further divided into 18 to 21 , 22 to 25,26 to 29,30 to 34 and 35 to 39 years old. Given that the risk coefficients between 18 and 39 years of age were for every ten years, the risk coefficient for the specific age groups in between were obtained through interpolation. The effective lifetime risk of radiation-induced thyroid cancer through brain CT examination was calculated using the formula given below (Brenner 2012):

$$
R=\Sigma r_{T} H_{T}
$$


where $\mathrm{R}$ is the effective lifetime risk; $r_{T}$ is the cancer lifetime attributable risk for tissue $\mathrm{T}$ per unit equivalent dose of that tissue, and $H_{T}$ is the equivalent dose for tissue T. Significance level was set at 0.05 , and SPSS version 22.0 (SPSS Inc., USA) was used for data analysis. The data were all presented as mean \pm standard deviation.

TABLE 1. Lifetime attributable risk of cancer incidence based on BEIR VII report

\begin{tabular}{|c|c|c|c|c|c|c|c|c|c|c|c|}
\hline \multirow{2}{*}{ Cancer site } & \multicolumn{11}{|c|}{ Age at Exposure (years) } \\
\hline & 0 & 5 & 10 & 15 & 20 & 30 & 40 & 50 & 60 & 70 & 80 \\
\hline \multicolumn{12}{|l|}{ Males } \\
\hline Stomach & 76 & 65 & 55 & 46 & 40 & 28 & 27 & 25 & 20 & 14 & 7 \\
\hline Colon & 337 & 285 & 241 & 204 & 173 & 125 & 122 & 113 & 94 & 65 & 30 \\
\hline Liver & 61 & 50 & 43 & 36 & 30 & 22 & 21 & 19 & 14 & 8 & 3 \\
\hline Lung & 314 & 261 & 216 & 180 & 149 & 105 & 104 & 101 & 89 & 65 & 34 \\
\hline Prostate & 93 & 80 & 67 & 57 & 48 & 35 & 35 & 33 & 26 & 14 & 5 \\
\hline Bladder & 209 & 177 & 150 & 127 & 108 & 79 & 79 & 76 & 66 & 47 & 23 \\
\hline Others & 1123 & 672 & 503 & 394 & 312 & 198 & 172 & 140 & 98 & 57 & 23 \\
\hline Thyroid & 115 & 76 & 50 & 33 & 21 & 9 & 3 & 1 & 0.3 & 0.1 & 0.0 \\
\hline All solid & 2326 & 1667 & 1325 & 1076 & 881 & 602 & 564 & 507 & 407 & 270 & 126 \\
\hline Leukimia & 237 & 149 & 120 & 105 & 96 & 84 & 84 & 84 & 82 & 73 & 48 \\
\hline All cancers & 2563 & 1816 & 1445 & 1182 & 977 & 686 & 648 & 591 & 489 & 343 & 174 \\
\hline \multicolumn{12}{|l|}{ Females } \\
\hline Stomach & 101 & 85 & 72 & 61 & 52 & 36 & 35 & 32 & 27 & 19 & 11 \\
\hline Colon & 220 & 187 & 158 & 134 & 114 & 82 & 79 & 73 & 62 & 45 & 23 \\
\hline Liver & 28 & 23 & 20 & 16 & 14 & 10 & 10 & 9 & 7 & 5 & 2 \\
\hline Lung & 733 & 608 & 504 & 417 & 346 & 242 & 240 & 230 & 201 & 147 & 77 \\
\hline Breast & 1171 & 914 & 712 & 553 & 429 & 253 & 141 & 70 & 31 & 12 & 4 \\
\hline Uterus & 50 & 42 & 36 & 30 & 26 & 18 & 16 & 13 & 9 & 5 & 2 \\
\hline Ovary & 104 & 87 & 73 & 60 & 50 & 34 & 31 & 25 & 18 & 11 & 5 \\
\hline Bladder & 212 & 180 & 152 & 129 & 109 & 79 & 78 & 74 & 64 & 47 & 24 \\
\hline Others & 1339 & 719 & 523 & 409 & 323 & 207 & 181 & 148 & 109 & 68 & 30 \\
\hline Thyroid & 634 & 419 & 275 & 178 & 113 & 41 & 14 & 4 & 1 & 0.3 & 0.0 \\
\hline All solid & 4592 & 3265 & 2525 & 1988 & 1575 & 1002 & 824 & 678 & 529 & 358 & 177 \\
\hline Leukimia & 185 & 112 & 86 & 76 & 71 & 63 & 62 & 62 & 57 & 51 & 37 \\
\hline All cancers & 4777 & 3377 & 2611 & 2064 & 1646 & 1065 & 886 & 740 & 586 & 409 & 214 \\
\hline
\end{tabular}




\section{RESULTS AND DISCUSSION}

Overall, 306 young adult patients' data were collected for this retrospective study. The effective lifetime risk for radiation induced thyroid cancer were calculated based on single and multiple brain CT examinations done. The effective lifetime risks were recorded as $0.45 \pm 0.70$ per 100000 and $0.93 \pm 1.52$ per 100000 for single and multiple exposures, respectively. The effective lifetime risk for radiation induced thyroid cancer through brain CT differed significantly $(\mathrm{p}<0.05)$ according to the number of exposures. The percentage difference of effective lifetime risks between single and multiple exposures was up to $107 \%$. For single exposures, the effective lifetime risk was $0.13 \pm 0.39$ and $0.99 \pm 0.76$ per 100000 for male and female, respectively. Meanwhile, for multiple exposures, the effective lifetime risk was $0.35 \pm 0.45$ and $1.95 \pm 2.15$ per 100000 for male and female, respectively (Table 2). The thyroid equivalent dose, which were calculated based on the absorbed dose by the thyroid organ were recorded as $1.15 \pm 1.76 \mathrm{mSv}$ and $2.68 \pm 1.97$ $\mathrm{mSv}$ for single and multiple exposure, respectively. The difference in thyroid equivalent dose for the exposures were statistically insignificant $(p>0.05)$. The effective lifetime risk between age groups for single exposure are $0.81 \pm 0.99,0.64 \pm 0.84,0.35 \pm 0.43,0.27 \pm 0.30$ and 0.18 \pm 0.36 per 100000 for 18 to 21,22 to 25,26 to 29,30 to 34 and 35 to 39 years old, respectively (Figure 1). Conversely, the readings were recorded as $0.95 \pm 1.04,2.96 \pm 3.81$, $0.57 \pm 0.85,0.68 \pm 0.72$ and $0.44 \pm 0.38$ per 100000 for 18 to 21,22 to 25,26 to 29,30 to 34 and 35 to 39 years old, respectively for multiple exposures.

TABLE 2. The comparison of genders and effective lifetime risks for the exposures

\begin{tabular}{cccc}
\hline \multicolumn{2}{c}{$\begin{array}{c}\text { Exposure/ } \\
\text { Gender }\end{array}$} & Number of cases & Effective lifetime risk, R (per 100 000) \\
\hline Single exposure & & 168 & $0.13 \pm 0.39$ \\
& Male & 102 & $0.99 \pm 0.76$ \\
Multiple exposure & Female & & \\
& Male & 23 & $0.35 \pm 0.45$ \\
& Female & 13 & $1.95 \pm 2.15$ \\
\hline
\end{tabular}

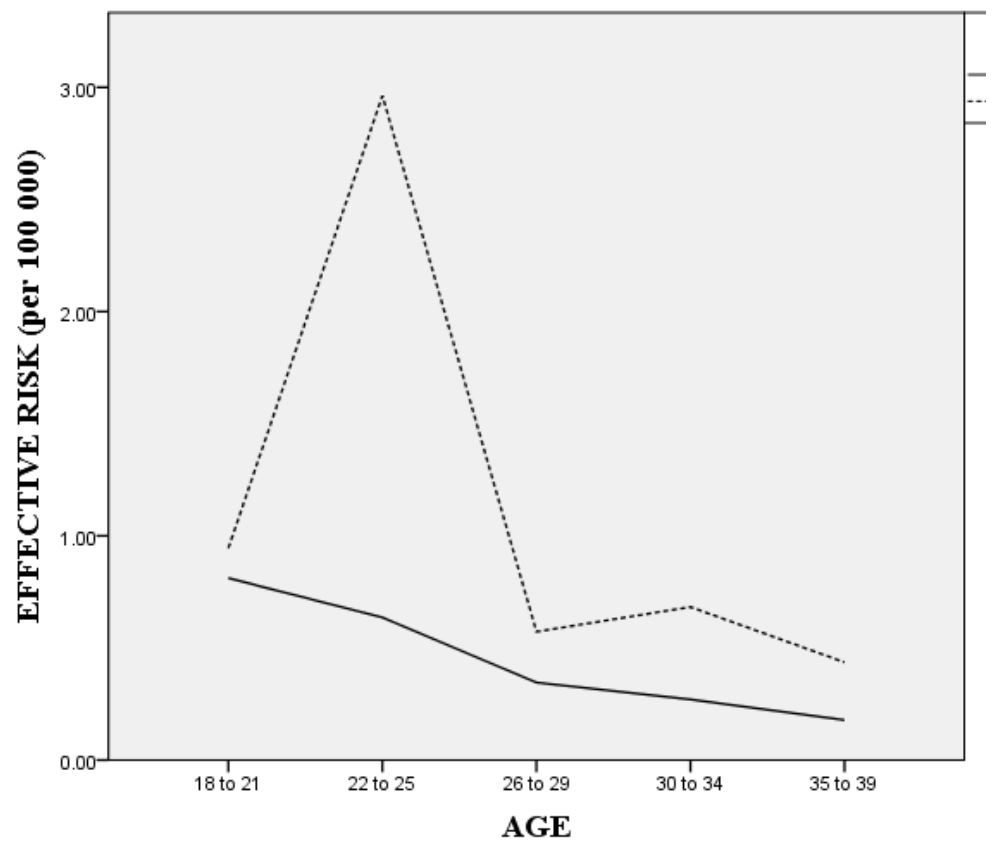

FIGURE 1. Mean effective lifetime risk against age based on exposure 
Multiple CT scan examinations done over a certain period of time is a widespread practice in hospitals around the globe (Ivanov et al. 2014; Zondervan et al. 2011). This is quite worrisome considering CT scan examination comprises of high doses of radiation delivered to patients. High cumulative dose experienced by patients increases risk of late radiation-induced cancer (Ivanov et al. 2014). The scattered radiation dose to the thyroid organ due to head CT examination is significant and can result in low but non-negligible development of thyroid cancer (Mazonakis et al. 2007). The results on effective lifetime risk proves that there is a possibility of radiation-induced thyroid cancer following $\mathrm{CT}$ examination of the brain no matter how small it may be. For a single exposure, the effective lifetime risk was $0.45 \pm 0.70$ per 100000 . This can be translated to about 1 in every 220000 people obtaining radiation-induced thyroid cancer through a single exposure of brain CT. Meanwhile, the possibility of radiation-induced thyroid cancer for multiple exposures of brain CT was recorded to be 1 in every 110000 people. As expected, the multiple exposures of brain $\mathrm{CT}$ resulted in a higher effective lifetime risk of radiation-induced thyroid cancer compared to single exposure with a percentage increase of up to $107 \%$. This is due to resulting high cumulative dose accompanying multiple exposures toward patients. Generally, the scan range for brain CT does not include the thyroid organ, however, there is no denying that some dose of radiation is absorbed by the thyroid organ through the scattered radiation (Chen et al. 2014; Ghaznavi 2020; Mazonakis et al. 2007; Watanabe et al. 2017). The highest number of multiple scans done in this study was up to six examinations, all within the span of one year. The effective lifetime risk for radiation induced thyroid cancer is directly proportional to the equivalent dose of the thyroid organ. On the same note, issue has been raised where CT has been used inappropriately. Ali et al. (2018) mentioned that no significance or need to obtain CT for nonlife-threatening conditions expected or trauma presented in headache management.

The thyroid equivalent dose is conceivably higher in multiple exposure compared to single exposure. This is most likely from the high cumulative absorbed dose of the thyroid organ in multiple exposures. The absorbed dose for this study was obtained through the input of scan parameters in WAZA ARI v2 (NIRS, Japan). There are other software such as ImPACT CT Patient Dosimetry and CT-Expo (Karim et al. 2016) that can be used in the calculation of the absorbed organ dose. However, WAZA ARI v2 was chosen because the organ doses are derived from Japanese male and female adult phantoms in addition to simulating the transport of photons from an X-ray tube to patient in CT modality (Takahashi et al. 2011). A Japanese adult has an average body mass index (BMI) of $22.5 \mathrm{~kg} / \mathrm{m}^{2}$ whereas a Malaysian adult has an average BMI of $24.37 \mathrm{~kg} /$ $m^{2}$ (Azmi et al. 2009). Since WAZA ARI was constructed based on Asian population that has similar average BMI to the average BMI of Malaysians, it is appropriate to be used in this study.

The effective lifetime risk between genders differed regardless of the number of exposures. It can be seen that the female had a higher risk of radiation induced thyroid cancer compared to the males in both single and multiple exposures. This is quite worrisome as the number of thyroid cancer incidence reported to increase significantly among Malaysian female for the last five years (National Cancer Institute 2019). Generally, it is known that the male population is more prone to developing cancer compared to female population (Tevfik Dorak \& Karpuzoglu 2012). However, some cancers with a higher incidence rate in female population compared to the male population; one of them is the thyroid cancer (Albi et al. 2017; Edgren et al. 2012). In the nuclear disaster that took place in Hiroshima and Nagasaki, the exposure to low or moderate doses of ionising radiation caused an increased risk of obtaining thyroid papillary microcarcinoma among adult female survivors (Albi et al. 2017). Based on the data from the Life Span Study (LSS) cohort that took place in Japan, the ratio of female to male in obtaining thyroid cancer is $4: 1$ (2009). In the BEIR VII, the lifetime attributable cancer risk is higher for females compared to the males indicating that female have a higher tendency to contract radiation-induced thyroid cancer (2006). The lifetime tissue-specific cancer risk is age and gender specific as such the coefficients differ according to gender which also possibly contributed to the results of this study. The reason for the high incidence rate of thyroid cancer among women is highly speculated. Few said that it was due to the female sex hormone, oestrogen despite conflicting evidence (Chen et al. 2009; Cunha et al. 2011). Consequently, there is no definitive reason as to why females have a higher incidence rate compared to males (Asselin 2011; Russo \& Sundaramurthi 2019).

The age during the time of radiation exposure is one of the main factors embroiled in radiation-induced cancer. It has been said that paediatric patients have a much higher risk of attaining radiation-induced cancer compared to adults (Chen et al. 2014; Mazonakis et al. 2007). This is due to thyroid gland in children being very sensitive to radiation. It was said that the cancer burden is much lower in the young adult age group compared to those observed in children and those of older ages (Fidler et al. 2017). The physiology, pharmacology, and genomic 
properties of the young adult age group may differ from younger and older age groups, however, due to the lack of studies on biology of tumours in this particular age group, there is no significant evidence reported thus far (Bleyer et al. 2008; Trama et al. 2018). In this study, it was also noted that risks of radiation-induced thyroid cancer with single exposure decreased with an increase in age. In the age group of 18 to 21 years, there is a chance for 1 in every 120000 people of attaining thyroid cancer and these chances decreases further from there on. Sensitivity towards radiation decreases gradually prior to old age which increases it again later in life. This is proven by the excess relative risks (ERRs) reported in the LSS cohort of the atomic bomb survivors in Japan. It portrayed progressive decrease in cancer induction from childhood till 30 to 40 years of age (Hernández et al. 2015).

\section{CONCLUSION}

Overall, effective lifetime risk of radiation induced thyroid cancer following brain CT examination among young adults may be relatively low, but the long-term risk of cancer development should be considered. Cumulative dose through multiple CT scans can eventually cause radiation- induced cancer. This study implies that by recording the potential cancer risk associated with $\mathrm{CT}$ scan, CT radiation can be managed effectively ( $\mathrm{Li}$ et al. 2011) as part of referred data in optimizing scanning protocols considering local population. It is also important for radiologists and radiographers to weight in the risks and benefits in performing multiple CT (Zondervan et al. 2013) especially in young adult patients. Future study can be extended to include other radiosensitive organs; exploring the effective lifetime risk of radiation induced cancer following high radiation procedure.

\section{ACKNOWLEDGEMENTS}

We would like to thank Mr Anand Ram who has proofread this paper and the Department of Radiology, Chancelor Tuanku Muhriz Hospital for their cooperation during data collection. The author(s) declare(s) that there is no conflict of interest.

\section{REFERENCES}

Abdulkadir, M.K., Mat Rahim, N.A.Y., Mazlan, N.S., Daud, N.M., Shuaib, I.L. \& Osman, N.D. 2020. Dose optimisation in paediatric CT examination: Assessment on current scanning protocols associated with radiation dose. Radiation Physics and Chemistry 171: 108740. https://doi.org/10.1016/j. radphyschem.2020.108740.
Albi, E., Cataldi, S., Lazzarini, A., Codini, M., Beccari, T., Ambesi-Impiombato, F.S. \& Curcio, F. 2017. Radiation and thyroid cancer. International Journal of Molecular Sciences 18(5): 911. https://doi.org/10.3390/ijms18050911.

Ali, A.H.A., Al-Ghamdi, S., Karrar, M.H., Alajmi, S.A., Almutairi, O.S., Aldalbahi, A.M., Alotaibi, Y.M., Alruwaili, S.A. \& Elamin, A.Y. 2018. Is there a misuse of computed tomography in the diagnostic workup of headache? A restrospective record-based study in secondary health-care facility in Saudi Arabia. Journal of Family Medicine and Primary Care 7(2): 357-361.

Asselin, B.L. 2011. Epidemiology of childhood and adolescent cancer. In Nelson Textbook of Pediatrics, edited by Kliegman, R.M., Behrman, R.E., Stanton, B.F., Schor, N. \& St. Geme, J. Philadelphia: Saunders W.B. pp. 1725-1727e1. https://doi. org/10.1016/b978-1-4377-0755-7.00485-1.

Azmi, M.Y., Junidah, R., Siti Mariam, A., Safiah, M.Y., Fatimah, S., Norimah, A.K., Poh, B.K., Kandiah, M., Zalilah, M.S., Wan Abdul Manan, W.M., Siti Haslinda, M.D. \& Tahir, A. 2009. Body mass index (BMI) of adults: Findings of the Malaysian Adult Nutrition Survey (MANS). Malaysian Journal of Nutrition 15(2): 97-119.

Bleyer, A. 2007. Young adult oncology: The Patients and their survival challenges. CA: A Cancer Journal for Clinicians 57(4): 242-255. https://doi.org/10.3322/canjclin.57.4.242.

Bleyer, A., Barr, R., Hayes-Lattin, B., Thomas, D., Ellis, C. \& Anderson, B. 2008. The distinctive biology of cancer in adolescents and young adults. In Nature Reviews Cancer 8(4): 288-298. https://doi.org/10.1038/nrc2349.

Brenner, D.J. 2012. We can do better than effective dose for estimating or comparing low-dose radiation risks. Annals of the ICRP 41(3-4): 124-128. https://doi.org/10.1016/j. icrp.2012.07.001.

Chen, A.Y., Jemal, A. \& Ward, E.M. 2009. Increasing incidence of differentiated thyroid cancer in the United States, 19882005. Cancer 115(16): 3801-3807. https://doi.org/10.1002/ cncr.24416.

Chen, J.X., Kachniarz, B., Gilani, S. \& Shin, J.J. 2014. Risk of malignancy associated with head and neck ct in children: A systematic review. In Otolaryngology - Head and Neck Surgery (United States) 151(4): 554-566. https://doi. org/10.1177/0194599814542588.

Cunha, L.L., Ferreira, R.C., Marcello, M.A., Vassallo, J. \& Ward, L.S. 2011. Clinical and pathological implications of concurrent autoimmune thyroid disorders and papillary thyroid cancer. Journal of Thyroid Research 2011: 387062. https://doi.org/10.4061/2011/387062.

Edgren, G., Liang, L., Adami, H.O. \& Chang, E.T. 2012. Enigmatic sex disparities in cancer incidence. European Journal of Epidemiology 27(3): 187-196. https://doi. org/10.1007/s10654-011-9647-5.

Fidler, M.M., Gupta, S., Soerjomataram, I., Ferlay, J., SteliarovaFoucher, E. \& Bray, F. 2017. Cancer incidence and mortality among young adults aged 20-39 years worldwide in 2012: 
A population-based study. The Lancet Oncology 18(12): 1579-1589. https://doi.org/10.1016/S1470-2045(17)306770 .

Ghaznavi, H. 2020. Thyroid cancer risk in patients undergoing 64 slice brain and paranasal sinuses computed tomography. Frontiers in Biomedical Technologies 7(2): 100-104. https:// doi.org/10.18502/fbt.v7i2.3855.

Hernández, L., Terradas, M., Camps, J., Martín, M., Tusell, L. \& Genescà, A. 2015. Aging and radiation: Bad companions. In Aging Cell 14(2): 153-161. https://doi.org/10.1111/ acel.12306.

Ivanov, V.K., Kashcheev, V.V., Chekin, S.Y., Menyaylo, A.N., Pryakhin, E.A., Tsyb, A.F. \& Mettler, F.A. 2014. Estimating the lifetime risk of cancer associated with multiple CT scans. Journal of Radiological Protection 34(4): 825-841. https:// doi.org/10.1088/0952-4746/34/4/825.

Karim, M.K.A., Hashim, S., Sabarudin, A., Bradley, D.A. \& Bahruddin, N.A. 2016. Evaluating organ dose and radiation risk of routine CT examinations in Johor Malaysia. Sains Malaysiana 45(4): 567-573.

Li, X., Samei, E., Segars, W.P., Sturgeon, G.M., Colsher, J.G., Toncheva, G., Yoshizumi, T.T. \& Frush, D.P. 2011. Patientspecific radiation dose and cancer risk estimation in CT: Part II. Application to patients. Medical Physics 38(1): 408-419. https://doi.org/10.1118/1.3515864.

Mazonakis, M., Tzedakis, A., Damilakis, J. \& Gourtsoyiannis, N. 2007. Thyroid dose from common head and neck CT examinations in children: Is there an excess risk for thyroid cancer induction? European Radiology 17(5): 1352-1357. https://doi.org/10.1007/s00330-006-0417-9.

National Cancer Institute. 2019. Malaysia National Cancer Registry Report (MNCRR) 2012-2016. In National Cancer Registry. http://nci.moh.gov.my/index.php/ms/listpenerbitan/35-laporan/398-summary-of-malaysian-nationalcancer-registry-report-2007-2011.

Russo, M.M. \& Sundaramurthi, T. 2019. An overview of cancer pain: Epidemiology and pathophysiology. In Seminars in Oncology Nursing 35(3): 223-228. https://doi.org/10.1016/j. soncn.2019.04.002.

Sabarudin, A., Siong, T.W., Chin, A.W., Hoong, N.K. \& Karim, M.K.A. 2019. A comparison study of radiation effective dose in ECG-Gated coronary CT angiography and calcium scoring examinations performed with a dual-source CT scanner. Scientific Reports 9(1): 4374. https://doi.org/10.1038/s41598019-40758-5.

Schonfeld, S.J., Lee, C. \& Berrington de González, A. 2011. Medical exposure to radiation and thyroid cancer. Clinical Oncology 23(4): 244-250. https://doi.org/10.1016/j. clon.2011.01.159.

Su, Y.P., Niu, H.W., Chen, J.B., Fu, Y.H., Xiao, G.B. \& Sun, Q.F. 2014. Radiation dose in the thyroid and the thyroid cancer risk attributable to CT scans for pediatric patients in one general hospital of China. International Journal of Environmental Research and Public Health 11(3): 2793-2803. https://doi. org/10.3390/ijerph110302793.
Takahashi, F., Sato, K., Endo, A., Ono, K., Yoshitake, T., Hasegawa, T., Katsunuma, Y., Ban, N. \& Kai, M. 2011. WAZA-ARI: Computational dosimetry system for x-ray CT examinations. I. radiation transport calculation for organ and tissue doses evaluation using JM phantom. Radiation Protection Dosimetry 146(1-3): 241-243. https://doi. org $/ 10.1093 / \mathrm{rpd} / \mathrm{ncr} 160$.

Tevfik Dorak, M. \& Karpuzoglu, E. 2012. Gender differences in cancer susceptibility: An inadequately addressed issue. Frontiers in Genetics 3(NOV): 1-11. https://doi.org/10.3389/ fgene.2012.00268.

Trama, A., Botta, L. \& Steliarova-Foucher, E. 2018. Cancer burden in adolescents and young adults. The Cancer Journal 24(6): 256-266. https://doi.org/10.1097/ppo.0000000000000346.

Trevisi, G., Scerrati, A., Peppucci, E., DeWaure, C., Anile, C. \& Mangiola, A. 2018. What is the best timing of repeated CT scan in mild head trauma with an initially positive CT scan? World Neurosurgery 118: e316-e322. https://doi. org/10.1016/j.wneu.2018.06.185.

Watanabe, H., Noto, K., Shohji, T., Ogawa, Y., Fujibuchi, T., Yamaguchi, I., Hiraki, H., Kida, T., Sasanuma, K., Katsunuma, Y., Nakano, T., Horitsugi, G. \& Hosono, M. 2017. A new shielding calculation method for X-ray computed tomography regarding scattered radiation. Radiological Physics and Technology 10(2): 213-226. https://doi. org/10.1007/s12194-016-0387-9.

Zondervan, R.L., Hahn, P.F., Sadow, C.A., Liu, B. \& Lee, S.I. 2011. Frequent body CT scanning of young adults: Indications, outcomes, and risk for radiation-induced cancer. Journal of the American College of Radiology 8(7): 501-507. https://doi.org/10.1016/j.jacr.2010.12.025.

Zondervan, R.L., Hahn, P.F., Sadow, C.A., Liu, B. \& Lee, S.I. 2013. Body CT scanning in young adults: Examination indications, patient outcomes, and risk of radiation-induced cancer. Radiology 267(2): 460-469. https://doi.org/10.1148/ radiol.12121324.

Rekha Ganesan, Muhammad Ikhmal Naim Mohd Hilal, Iza Nurzawani Che Isa*, Norhashimah Norsuddin \& Khadijah Mohd Nassir

Diagnostic Imaging and Radiotherapy Programme

Faculty of Health Sciences

Universiti Kebangsaan Malaysia

Jalan Raja Muda Abdul Aziz

50300 Kuala Lumpur, Federal Territory

Malaysia

Said Mohd Shaffiq Said Rahmat

Department of Radiology

National Cancer Institute

62250 Putrajaya, Wilayah Persekutuan Putrajaya

Malaysia 
Muhammad Khalis Abd Karim

Department of Physics, Faculty of Sciences

Universiti Putra Malaysia

43400 UPM Serdang, Selangor Darul Ehsan

Malaysia
*Corresponding author; email: zawaniisa@ukm.edu.my

Received: 19 June 2020

Accepted: 7 March 2021 